\title{
Outbound Tourism Demand of Turkey: A Markov Switching Vector Autoregressive Approach
}

\section{Ceyhun Can Özcan', Harun Uçak ${ }^{2}$}

e-mail: ceyhuncan@hotmail.com / ucakharun@hotmail.com

'Faculty of Tourism, Necmettin Erbakan University, Konya, Turkey

${ }^{2}$ Faculty of Business, Alanya Alaaddin Keykubat University, Alanya, Turkey

Özcan, C. C., \& Uçak, H. (2016). Outbound Tourism Demand of Turkey: A Markov Switching Vector Autoregressive Approach. Czech Journal of Tourism, 5(2), 59-72. DOI: 10.1515/cjot-2016-0004.

\begin{abstract}
Tourism has been one of the fastest-growing sectors in the world. Especially developed countries have been major markets for tourism destinations over the decades. Furthermore, the outbound tourism demand in emerging markets has increased rapidly in recent years. This study aims to investigate the determinants of Turkey's outbound tourism demand by using the data from 1960 to 2013. For this purpose, the Markov Switching Vector Autoregressive Model is used as an empirical analysis. This model classifies the time period into different regimes in order to obtain more robust results. Finally, our findings show that Turkish citizens' outbound visits have been influenced by income and the exchange rates.
\end{abstract}

\section{Key words}

Outbound tourism, tourism sector, Markov Switching Vector Autoregressive Model, Turkey

JEL classification: Z32, C32, L83 


\section{Introduction}

In recent decades, tourism has become one of the fastest-growing economic sectors in the world, with significant economic and social contributions to many countries. The United Nations World Tourism Organization [UNWTO] (2014) indicated that about 1.1 billion tourists took an international trip every year, and tourism continues to be an unstoppable force and a key driver of the global economic recovery. Furthermore, tourism income has taken an important place in the countries' Gross Domestic Products as an increasing trend. Hence, a growing number of countries and regions have increased their investments in the tourism sector due to these economic impacts.

Figure 1 Global Process of Outbound Tourism

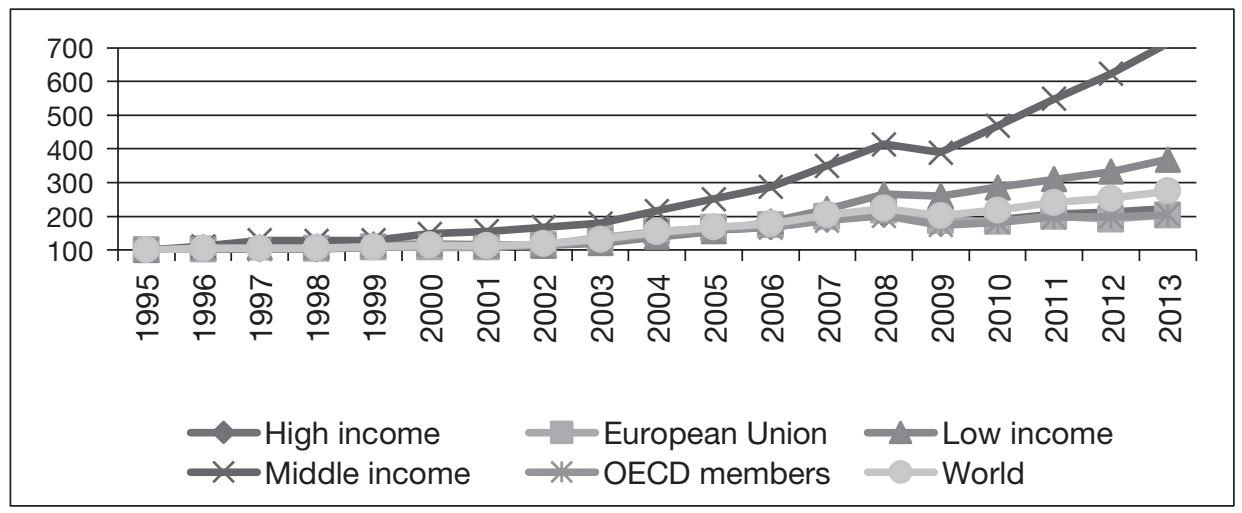

Source: The World Bank (2015)

While the tourism sector has shown the growth in the world, it should be noted that the outbound tourism expenditure has also increased. The income of destinations results in the expenditure of countries that are the source of the market. Globalization has encouraged the individuals' international travel demands with the developments of information and transportation technologies. An increasing number of households have been considering the outbound spending in their budgets, and the world international tourism expenditure was increased from 464 Billion USD to 1.27 Trillion USD from 1995 to 2013. Figure 1 shows the outbound tourism trend of the world and selected country groups, with a base reference year as $1995=100$. The outbound tourism has been on a rapid-growth trend for all country groups since 2000. Furthermore, tourism expenditure of the middle-income countries has increased more than those of other country groups. 
Figure 2 Recent Income and Expenditure Process of Tourism Sector in Turkey (Million \$)

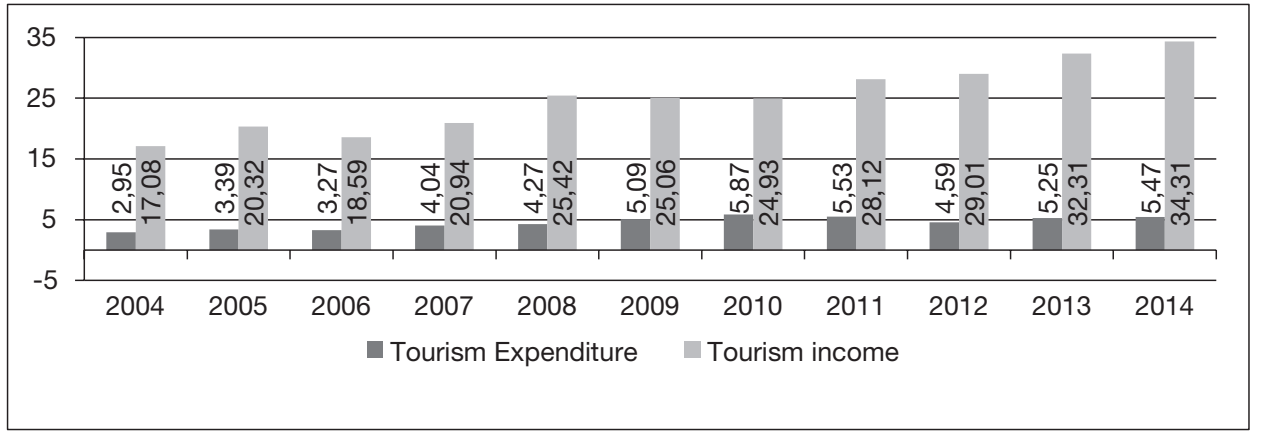

Source: Turkish Statistical Institute (2015)

Turkey is considered a tourism destination due to its role in the Turkish economy. The inbound tourism income reached 34 billion USD in 2014. However, the outbound tourism expenditure is quite low when compared with the inbound tourism income. Hence, most of the studies have focused on the inbound tourism and its determinants. However, the outbound tourism demand has increased and investigating effects on it are necessary. As illustrated in Figure 2, the international tourism expenditure of Turkey reached 5.47 billion USD, with 8.36 million visitors in 2014. Among the destinations, Georgia has been the most popular country for Turkish citizens in recent years thanks to its neighbourliness and also thanks to the significant effect of the visa exemption agreement between both countries (Uçak, 2011). The visa effects on the outbound tourism was identified by the Turkish Statistical Institute (TURKSTAT) [TSI] data, as 1.2 million Turkish citizens visited Georgia from Turkey in 2014, but it was only 54,626 people in 2005.

\section{Literature Review}

In literature, the inbound tourism demand for a country or region was tested widely due to its increasing importance of the sector as an economic contribution. However, the studies on the outbound tourism are scarce, but there has been an increasing number of empirical attempts in this field. The developed countries have been an important source of the international market for a long time and the initial outbound tourism research focused on their demand patterns. For example, Song et al. (2000) studied the UK's outbound tourism demand, which was applied in 12 different destinations and their findings show that the income and price elasticity of demand is quite high for travels to overseas countries. Hamal (1998) studied the Australian outbound holiday travel demand and the author concluded that the demand was affected highly by domestic travel and accommodation prices. As a more recent empirical application for Australia, Seetaram (2010) found that income was the single most important determinant of departure from Australia both in the short and in the long run. Lim (2004) analyzed the pattern of tourist arrivals from South Korea to Australia by using the data of changes 
in income, relative prices, exchange rates, seasonality and other factors such as lagged value of tourist arrivals, to capture the hysteresis effect of past visits. The results of the study show that the international tourism demand by South Korea is both income elastic and price elastic. Kim et al. (2012) examined the Korean household asset effects on outbound travelling and their findings show the possibility of a significant wealth effect from housing on the outbound travel demand, but not from the financial assets. Che (2013) investigated the Taiwanese outbound tourism and the results show that a destination country's consumer price index (CPI) has a positive linear relation with the number of Taiwanese people travelling abroad. Ziramba and Moyo (2013) identified the determinants of the outbound tourism demand in South Africa and the authors found that outbound tourism demand was influenced by the real domestic income and the relative prices in the long run.

\section{Methodology}

Based on the literature review, the Gross Domestic Product (GDP) per capita and real exchange rate variables are used for empirical application in order to investigate the determinants of the outbound tourism.

TOUR $R_{t}=\mathrm{a}_{0}+\mathrm{b}_{1} P G D P_{t}+\mathrm{b}_{2} E R_{t}+\mathrm{e}_{t}$

In Equation (1), TOUR shows the total of the outbound tourist numbers for Turkey. $P G D P$ denotes the real GDP per capita in US dollars. ER shows the nominal Turkish lira/US dollar exchange rate. In addition, two variables that are common macroeconomic variables employed to measure effects of macroeconomic environment are also included. The data is taken from the Turkish Statistical Institute (TSI) and Central Bank of the Republic of Turkey [CBRT] Electronic Data Distribution System. The model is tested by using the annual data from 1960 to 2013. Furthermore, all data are in a logarithmic form of the model. The trends of the variables are illustrated in Figure 3.

The rationality and theoretically expected effects of the variables in Equation (1) can be expressed as follows:

$b_{1}>0$ : An increase in the income (PGDP) of household will increase the outbound demand for tourism of Turkey (TOUR) (Aslan, Kaplan, \& Kula, 2008; GarinMunoz, 2006; Garin-Munoz \& Montero-Martín, 2007; Naude \& Saayman, 2005; Özcan, 2013; Walle, 2010).

$b_{2}>0$ : An increase in the nominal exchange rate $(E R)$ will decrease the demand for the outbound tourism because it will make tourism abroad relatively expensive in comparison with domestic destinations. Thus, the depreciation in national currency will reduce the outbound tourism demand (Lee \& Chang, 2008; Maloney \& Rojas, 2013; Özcan, 2013; Uçak, 2011; Webb \& Chotithamwattana, 2013). 
Figure 3 Graphical Representation of Variables (1960-2013)

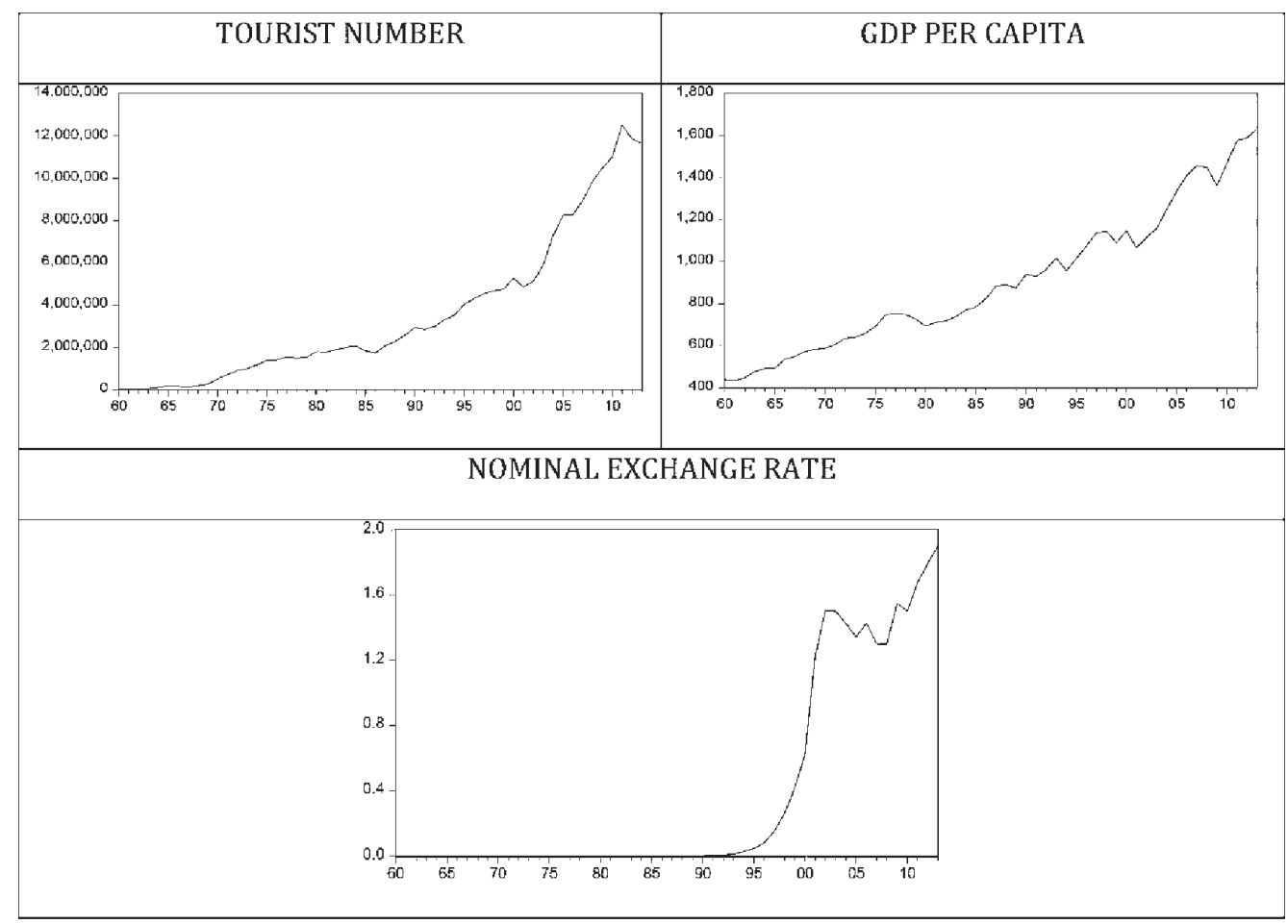

Source: TSI (2015) and CBRT (2015)

The empirical methodology involves the Markov Switching Vector Autoregressive Model (MS-VAR), applied on an estimation of the outbound tourism demand. The tourism sector is quite a sensitive sector and included structural breaks in the long period from 1960 to 2013. That would be reason for regime shifts in the sector. Moreover, business cycles are quite effective on the tourism sector and induce similar regime shifts in the tourism sector. Hence, MS-VAR is a good tool for monitoring the asymmetric behaviors in the historical process and it has the advantage that one can accommodate structural changes across the regimes, both with respect to the autoregressive dynamics and the covariance structure of shocks (Binder \& Gross, 2013).

The MS-VAR method examines behaviors of the time series in different regimes. The switching mechanism is controlled by an unobservable random variable. For detailed information about the MS - VAR methodology, please consult (Fallahi \& Rodriguez, 2007; Kayhan et al., 2013; Mohd \& Zahid, 2006). 


\section{Empirical Results}

In empirical applications of times series, the stationary of variables checked before the estimation of models and macroeconomic time series often do not show any stationary. This is one of the main problems faced in the studies of time series. It can cause a relationship to be obtained, which does not indeed exist between the variables used in the model. For the results to be reliable, before the prediction of a model, it is necessary to examine the stationarity of the variables used in the study. In order to test the presence of the unit root, there are different methods (Harris \& Sollis, 2003). It is also important to investigate descriptive statistics of series, which is useful for understanding the nature of the presented data.

Table 1 Descriptive Statistics of Variables

\begin{tabular}{|l|r|r|r|r|r|r|r|}
\hline & \multicolumn{1}{|c|}{ Mean } & \multicolumn{1}{|c|}{ Maximum } & Minimum & $\begin{array}{c}\text { Standard } \\
\text { Deviation }\end{array}$ & Skewness & Kurtosis & Jarque-Bera \\
\hline ER & 0.390892 & 1.903768 & $9.02 \mathrm{E}-06$ & 0.644693 & 1.214831 & 2.680465 & $\begin{array}{r}13.51206 \\
0.001164\end{array}$ \\
\hline PGDP & 907.1322 & 1634.483 & 433.9560 & 333.9739 & 0.538369 & 2.294307 & 3.729079 \\
& & & & & & & 0.154968 \\
\hline TOUR & 3559898. & 12513018 & 28211.00 & 3540165. & 1.143272 & 3.218662 & 11.87121 \\
& & & & & & & 0.002644 \\
\hline
\end{tabular}

Source: authors' own

According to the descriptive statistics, variables have similar statistic specifications. Skewness values show that series are biased to the right. However, series are considerably flat.

In order to examine the features of the time series of the variables, Dickey Fuller (DF) and Augmented Dickey Fuller (ADF) are preferred. Since DF and ADF tests are sensitive to lagging lengths, the compliant value to be selected of lagging length must be small not to mislead the calculations made and at the same time, big in order not to cause the autocorrelation among the error time. The analysis of the results is summarized in Table 1. 
Table 2 ADF Results of the Unit Root Test

\begin{tabular}{|c|c|c|c|c|c|}
\hline \multicolumn{2}{|l|}{ Variables } & \multicolumn{2}{|c|}{ ADF t statistics (Level) } & \multicolumn{2}{|c|}{ ADF - t statistics (First Difference) } \\
\hline & & Without Trend & With Trend & Without Trend & With Trend \\
\hline \multicolumn{2}{|l|}{ TOUR } & 2.622 & -0.406 & -5.283 & -5.975 \\
\hline \multicolumn{2}{|l|}{ PGDP } & -3.153 & -2.228 & -3.400 & -3.785 \\
\hline \multicolumn{2}{|l|}{ ER } & 0.388 & -1.256 & -4.194 & -4.558 \\
\hline \multirow[t]{3}{*}{ Significance Level } & $\% 1$ & -3.562 & -4.144 & -3.562 & -4.144 \\
\hline & $\% 5$ & -2.918 & -3.498 & -2.918 & -3.498 \\
\hline & $\% 10$ & -2.597 & -3.178 & -2.597 & -3.178 \\
\hline
\end{tabular}

Source: authors' own

According to Table 2, it is seen that the unit root results carried out for all of TOUR, PGDP and ER series are stationary at Level (1). According to the test results in Table 2 , the variables included the unit root in the values of level should be further analyzed, taking their first differences.

Table 3 Determination of the Regime Number and the Test Statistics

\begin{tabular}{|l|c|c|c|c|c|}
\hline Regime Number & Log Probability & LR Linearity & Davies & AIC & SC \\
\hline MS(2) & -443.6774 & $417.4515(0.00)$ & 0.00 & 21.9921 & 41.2945 \\
\hline MS(3) & -437.5563 & $419.1219(0.00)$ & 0.00 & 22.1842 & 39.7139 \\
\hline MS(4) & -441.1780 & $421.22568(0.00)$ & 0.00 & 21.6525 & 38.1125 \\
\hline
\end{tabular}

Source: authors' own

According to the initial results, it is clear that the number of regimes should be four. The Schwarz and Akaike information criteria have the smallest value in the four regime models. In addition, the lag length is determined by four criteria: SC LR, FPE and HQ and it is chosen as 2. Furthermore, in the length of this lagging, it was determined that the model established did not include any autocorrelation and varying variance by utilizing LM and White Test.

Table 4 Regime Probabilities

\begin{tabular}{|l|c|c|}
\hline Obs & Prob & Duration \\
\hline Regime 1 & 24.4 & 1.87 \\
\hline Regime 2 & 26.6 & 3.87 \\
\hline Regime 3 & 24.6 & 1.91 \\
\hline Regime 4 & 23.5 & 3 \\
\hline
\end{tabular}

Source: authors' own 
The unconditional probability of regime 1 is $24.4 \%$, and the average duration of regime one, if the economy enters it, is 1.87 years. However, the unconditional probability of entering the second regime is $26.6 \%$, and it takes 3.87 years on average. While the unconditional probability of entering the third regime is $24.6 \%$, it takes 3.53 years on average. The regime four's average duration is 1.91 years, and the unconditional probability of entering it is $23.5 \%$.

Table 5 Regime Transition Probability

\begin{tabular}{|l|c|c|c|c|}
\hline & Regime 1 & Regime 2 & Regime 3 & Regime 4 \\
\hline Regime 1 & 0.4755 & 0.1122 & 0.1373 & 0.2750 \\
\hline Regime 2 & 0.1789 & 0.7455 & 0.0390 & 0.0377 \\
\hline Regime 3 & 0.0919 & 0.0315 & 0.7177 & 0.1609 \\
\hline Regime 4 & 0.2593 & 0.1297 & 0.1356 & 0.4754 \\
\hline
\end{tabular}

Source: authors' own

The probabilities of regime transition are provided in Table 5. According to this, while the economy is in the first regime, the probability to enter the first regime again is $47 \%$. The transition probability from the first regime to the second and third regimes is $11 \%$ and $13 \%$, respectively. The probability of entering the fourth regime is $27 \%$.

While the economy is in the second regime, the probability of staying in the same regime is $74 \%$. To enter the first regime, it is $17 \%$, while it is only $3 \%$ for both the third and fourth regimes. Similarly, the probability of staying in the third regime, while the economy is in the third regime, is $71 \%$. The transition to the fourth regime probability is $16 \%$, and it is $9 \%$ and $3 \%$, respectively.

The possibility of an extension in the fourth regime is $47 \%$, while the economy is still in the fourth regime. The transition to the first regime is higher than others; it is $25 \%$. The transition probability to the second and third regimes is $12 \%$ and $13 \%$, respectively.

The way how the variables considered affected the outbound tourism demand of Turkey in different regimes is examined by means of impulse-response functions. As it is illustrated in Tables 6, 7, 8 and 9, the impulse on the outbound tourism demand provides the exchange rate, and PGDP variables show the differentiation in both periods.

If Table 6 is examined in the first regime, the shock in tourist demand affects the exchange rate positively, and it is statistically significant for a long time period, but the effect is weak. However, the positive shock in the tourist number affects GDP negatively. It is insignificant, both statistically and economically. The shock of $1 \%$ occurring in PGDP makes a positive effect on the number of tourists. It indicates that the variation occurring in PGDP has a significant effect on the number of tourists. It can be observed that the effect on the exchange rate is positive, but it is statistically significant for a short time period. 
Figure 4 Probabilities of the Regimes

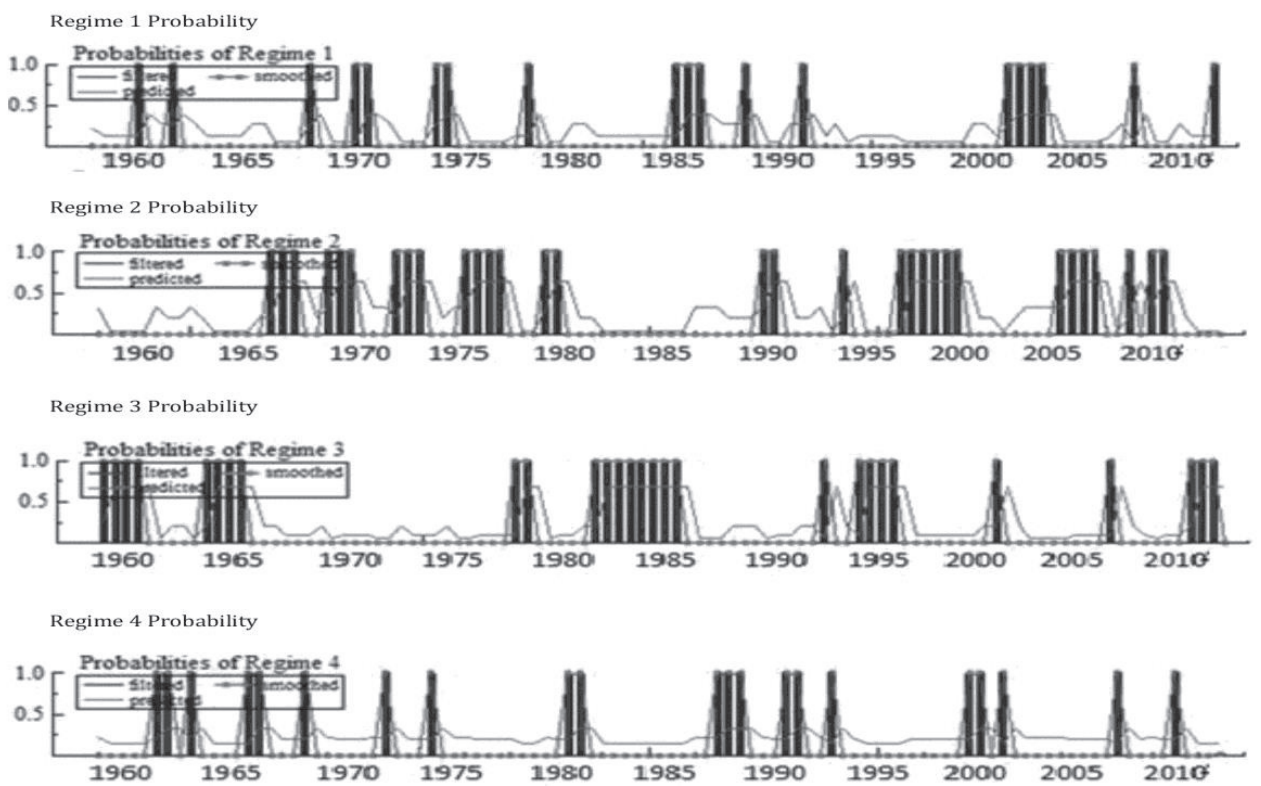

Source: authors' own

It can be concluded that a positive shock occurring in the exchange rate created a negative effect on the number of tourists; it is statistically significant. Similarly, it can be seen that the effect of the shock in the exchange rate on PGDP is also positive, but it is statistically insignificant.

Table 6 Impulse-Response Function in the First Regime

\begin{tabular}{|l|c|c|c|c|c|c|c|c|c|}
\hline \multicolumn{3}{|c|}{ Response of Variables, Shock in TOUR } & \multicolumn{2}{l|}{ Response of Variables, Shock in PGDP } & \multicolumn{3}{|c|}{ Response of Variables, Shock in ER } \\
\hline & TOUR & PGDP & $\boldsymbol{E R}$ & TOUR & $\boldsymbol{P G D P}$ & $\boldsymbol{E R}$ & TOUR & $\boldsymbol{P G D P}$ & $\boldsymbol{E} \boldsymbol{}$ \\
\hline $\mathbf{1}$ & 1.120 & -0.327 & 0.000 & 1.240 & 0.600 & 0.000 & -0.900 & 1.040 & 0.291 \\
\hline $\mathbf{2}$ & 1.00 & 0.828 & 0.002 & 1.620 & 0.841 & 0.007 & 0.628 & -0.441 & 0.279 \\
\hline $\mathbf{3}$ & 4.330 & -1.250 & 0.003 & 1.140 & 0.634 & -0.004 & 0.079 & 0.932 & 0.200 \\
\hline $\mathbf{4}$ & -1.110 & -0.404 & 0.002 & 0.680 & 0.751 & 0.027 & -1.260 & -0.867 & 0.380 \\
\hline $\mathbf{5}$ & 1.540 & 0.571 & -0.017 & -3.800 & 0.882 & 0.003 & -0.256 & 1.610 & 0.140 \\
\hline $\mathbf{6}$ & 1.550 & -1.330 & 0.032 & 1.310 & 2.280 & -0.046 & 1.060 & -0.286 & 0.070 \\
\hline $\mathbf{7}$ & -0.682 & 1.150 & -0.023 & -1.240 & -0.711 & 0.208 & -2.210 & -0.543 & 1.910 \\
\hline $\mathbf{8}$ & 1.740 & 2.430 & -0.077 & -1.440 & 1.420 & -0.291 & 2.780 & 1.710 & -3.390 \\
\hline $\mathbf{9}$ & -2.030 & -1.120 & 0.286 & 0.988 & -0.232 & 0.030 & 0.610 & -2.260 & 5.610 \\
\hline $\mathbf{1 0}$ & -1.920 & 2.020 & -0.470 & -1.920 & 0.437 & 1.300 & -2.300 & -0.745 & 3.780 \\
\hline
\end{tabular}

Source: authors' own 
In Table 6, which deals with the second regime, it can be concluded that the effect of the positive shock occurring in the number of tourists on PGDP is negative and theoretically significant. The results of the impulse-response in the number of tourists indicate a significant response against the positive shock, which was also theoretically expected. It can be concluded that, while the positive shock occurring in PGDP has a positive and significant effect on the number of tourists in the first period, it early turns negative and becomes insignificant. It can be concluded that the effect of the shocks in the exchange rate on the number of tourists is positive and theoretically insignificant for the tourist number. However, the response of GDP to the shock in the exchange rate is positive and statistically significant. It can be interpreted that an increase in the exchange rate would increase competitiveness of the export sectors, and the amount of exports would increase. This is a good result for implementing an export-led growth model in Turkey.

Table 7 Impulse-Response Function in the Second Regime

\begin{tabular}{|l|c|c|c|c|c|c|c|c|c|}
\hline \multicolumn{3}{|c|}{ Response of Variables, Shock in TOUR } & \multicolumn{3}{|c|}{ Response of Variables, Shock in PGDP } & \multicolumn{3}{|c|}{ Response of Variables, Shock in ER } \\
\hline & TOUR & PGDP & ER & TOUR & PGDP & ER & TOUR & PGDP & ER \\
\hline $\mathbf{1}$ & 0.342 & -0.192 & -0.001 & 0.559 & 0.240 & 0.087 & 0.741 & 0.819 & 1.320 \\
\hline $\mathbf{2}$ & 0.097 & -0.225 & -0.001 & -1.440 & 1.140 & 0.044 & -0.819 & 1.080 & 0.819 \\
\hline $\mathbf{3}$ & 0.313 & -0.378 & 0.078 & 4.490 & 0.974 & 0.018 & -2.230 & 0.561 & 1.970 \\
\hline $\mathbf{4}$ & 0.128 & 0.511 & 0.023 & -7.300 & 3.780 & -0.093 & -1.335 & -1.340 & -0.526 \\
\hline $\mathbf{5}$ & 0.378 & -0.689 & 0.001 & 3.910 & 0.504 & -0.075 & 1.445 & -1.760 & -0.758 \\
\hline $\mathbf{6}$ & -2.230 & -0.396 & -0.073 & -3.460 & -0.829 & -0.032 & 1.890 & -2.320 & -0.350 \\
\hline $\mathbf{7}$ & 0.914 & 0.179 & -0.092 & -8.670 & 1.791 & -0.151 & 1.630 & -1.190 & 0.930 \\
\hline $\mathbf{8}$ & 3.000 & -3.440 & 0.007 & 5.150 & -0.378 & 0.094 & 2.620 & 1.640 & 2.760 \\
\hline $\mathbf{9}$ & -0.261 & 2.380 & 0.005 & -5.090 & 2.250 & -0.127 & 3.030 & 1.670 & 0.474 \\
\hline $\mathbf{1 0}$ & 2.850 & 1.890 & 0.066 & 4.880 & 0.652 & 0.562 & -0.636 & 0.361 & 1.900 \\
\hline
\end{tabular}

Source: authors' own

In the third regime, the positive shock in the tourist number would affect GDP negatively. Although it is statistically significant, theoretically, an increase in the tourist number would raise GDP. The shock would reduce the exchange rate. The results might be meaningful, but they are statistically insignificant. The results indicate that the positive shock in GDP affects the tourist number negatively and it is insignificant. However, the response of the exchange rate to it would be positive. It is significant, both statistically and economically. Last, the positive shock in the exchange rate would reduce the tourist number and GDP. It is insignificant, both statistically and economically, because an increase in the exchange rate would raise GDP via an export increase and it would also make Turkey cheaper for foreign tourists, compared to other countries. 
Table 8 Impulse-Response Function in the Third Regime

\begin{tabular}{|l|c|c|c|c|c|c|c|c|c|}
\hline \multicolumn{3}{|c|}{ Response of Variables, Shock in TOUR } & \multicolumn{3}{|c|}{ Response of Variables, Shock in PGDP } & \multicolumn{3}{|c|}{ Response of Variables, Shock in ER } \\
\hline & TOUR & PGDP & ER & TOUR & PGDP & ER & TOUR & PGDP & ER \\
\hline $\mathbf{1}$ & 0.228 & -0.013 & -0.001 & -0.519 & 1.000 & 0.000 & -0.160 & -0.816 & 0.188 \\
\hline 2 & 0.123 & -0.184 & 0.033 & 0.717 & 0.428 & 0.010 & 0.115 & -0.399 & 0.207 \\
\hline 3 & 0.348 & -0.329 & 0.053 & 1.120 & 0.557 & 0.002 & 0.037 & 0.855 & 0.042 \\
\hline 4 & 0.455 & 0.198 & 0.087 & 1.190 & -1.620 & -0.103 & -0.250 & -1.650 & -0.014 \\
\hline 5 & 0.354 & -0.186 & 0.007 & -2.160 & 1.650 & -0.024 & -0.250 & 0.884 & -0.101 \\
\hline 6 & 0.147 & 0.052 & 0.000 & -0.310 & 0.221 & 0.000 & 0.260 & -0.585 & 0.222 \\
\hline 7 & 0.597 & 0.326 & 0.045 & -0.011 & 0.222 & -0.043 & -0.335 & -0.217 & -0.314 \\
\hline 8 & -0.215 & -0.975 & -0.031 & -0.128 & 1.430 & 0.037 & -0.260 & -0.177 & 0.255 \\
\hline 9 & -0.289 & 0.257 & 0.006 & 1.180 & -2.130 & -0.067 & -0.851 & -1.700 & -1.010 \\
\hline 10 & 0.264 & -0.149 & 0.000 & 0.898 & 2.160 & -0.001 & 0.196 & 3.060 & 0.580 \\
\hline
\end{tabular}

Source: authors' own

Table 9 Impulse-Response Function in the Fourth Regime

\begin{tabular}{|l|c|c|c|c|c|c|c|c|c|}
\hline \multicolumn{4}{|c|}{ Response of Variables, Shock in TOUR } & \multicolumn{3}{|c|}{ Response of Variables, Shock in PGDP } & \multicolumn{3}{|c|}{ Response of Variables, Shock in ER } \\
\hline & TOUR & PGDP & ER & TOUR & PGDP & ER & TOUR & PGDP & ER \\
\hline $\mathbf{1}$ & 0.559 & -0.107 & -0.001 & -0.810 & 0.138 & -0.017 & -0.010 & 0.013 & 0.065 \\
\hline 2 & 0.488 & -0.016 & -0.001 & 0.019 & 0.031 & 0.106 & 0.104 & -0.168 & 0.168 \\
\hline 3 & 1.810 & 0.211 & 0.014 & -0.551 & -1.790 & -0.012 & -0.191 & 0.232 & 0.309 \\
\hline 4 & -0.746 & -0.131 & -1.012 & 1.180 & -2.010 & 0.014 & 0.421 & -0.550 & 0.736 \\
\hline 5 & 1.466 & -1.130 & 0.021 & -3.810 & 1.670 & -1.062 & -0.637 & 2.170 & -1.810 \\
\hline 6 & -2.330 & 1.040 & -0.0139 & 1.120 & -0.790 & 0.102 & 0.809 & -2.530 & 1.510 \\
\hline 7 & 3.103 & -0.907 & 1.050 & -0.130 & 0.090 & -0.217 & -0.765 & 4.070 & -1.470 \\
\hline 8 & -2.110 & 1.510 & -1.047 & 1.040 & -0.640 & 0.203 & -0.014 & -5.090 & 0.466 \\
\hline 9 & -1.150 & -1.100 & 0.105 & -1.010 & 2.390 & -1.235 & 2.330 & 5.330 & 0.780 \\
\hline 10 & 9.470 & 1.640 & 1.122 & -0.510 & -1.010 & 1.011 & -0.190 & -0.020 & -2.090 \\
\hline
\end{tabular}

Source: authors' own

In the fourth regime, the positive shock in the tourist number would reduce GDP and the exchange rate for a short time period. Although it is statistically significant, it is not meaningful for the theory of economics. It is expected that an increase would raise GDP. However, neither the positive shock in GDP, nor the exchange rate affects the tourist number significantly. 


\section{Conclusion}

The variation occurring in the expenditure of Turkey abroad is highly above the average of the world. In addition, the average expenditure of the outbound Turkish tourists is above the average expenditure of the inbound foreign visitors in Turkey. Furthermore, the income and exchange rate variables are important determinants of the outbound tourism demand of the Turkish citizens. However, the decrease of the noneconomic prevention such as transportation in the tourism market, increase of leisure times, removal of political barriers and visa restriction, can be effective in the increase of international tourism demand. Together with the increase of tourist activities, especially after $1980 \mathrm{~s}$, it can be seen that the international tourism demand gains importance (TSI, 2015).

In this study, the international tourism demand of Turkey since 1960 has been examined by means of MS VAR analysis. This method provides important findings about the direction and effect of the parameters affecting the international tourism demand in different regimes, according to the other time series analyses. Especially the international tourist number, consisting of four different regimes, is one of the important findings. According to the results, GDP reacts positively and strongly to a change in the tourist number and exchange rate in the first and second regimes. However, the response of GDP to shocks in other variables is low in the third and fourth regimes.

According to the regime probability results, it can be concluded that the probability of existence for each regime is very similar, but the duration of each regime is slightly different. According to the results, the duration of the first and second regimes equal to the third and fourth regimes which show similar behavior. Moreover, the response of the tourist number is more sensitive to the GDP shocks and the exchange rate changes in the first binary regimes. The shock in GDP would increase in the first regime, as expected. On the contrary, the exchange rate shocks would increase the number of tourists positively in the second regime. But the effect would be weak and statistically insignificant.

However, the GDP and exchange rate variables do not affect the tourist number. The positive shocks occurring in both variables do not affect the number of tourists in any case. Especially in the third and fourth regimes, the behavior of people who are curious about the economic situation would be pessimistic and they would be disposed of the tourist service demand. In this case, the tourist demand would not be affected, neither by GDP nor by the exchange rate shocks.

Finally, two suggestions for further research can be presented: First, this study only focuses on some of the macro determinatives of the outbound tourism demand of Turkey. Besides including the different macroeconomic variables in the model, the scope of this study can be extended. Second, in the study, the determinativeness of demand in the different regimes is empirically tested, however, projection or prediction about the future is not provided. In the light of these findings, the demand prediction can be made. Third, reaction to the tourism demand in different kinds of shocks, specifically, the positive and negative ones, can be explored. Investigating the direction of the response to the tourism demand in positive or negative GDP and exchange rate shocks would increase the predictability of tourism demand changes in economy. 


\section{References}

Aslan A., Kaplan M., \& Kula F. (2008). International Tourism Demand for Turkey: A Dynamic Panel Data Approach. MPRA - Munich Personal RePEc Archive, Paper No. 10601. http://mpra. ub.uni-muenchen.de/10601/.

Binder, M., \& Gross, M. (2013). Regime-Switching Global Vector Autoregressive Models. Working Paper Series, No 1569, August. Frankfurt, Germany: European Central Bank. https://www.ecb. europa.eu/pub/pdf/scpwps/ecbwp1569.pdf.

Central Bank of the Republic of Turkey. (2015). Electronic data delivery system. Retrieved 1 February, 2015 from http://evds.tcmb.gov.tr/cbt.html.

Che, C. M. (2013). Panel threshold analysis of Taiwan's outbound visitors. Economic Modelling, 33(July), 787-793. DOI: 10.1016/j.econmod.2013.06.006.

Fallahi, F., \& Rodriguez, G. (2007). Using Markov-Switching Models to Identify the Link Between Unemployment and Criminality. Working Papers, no. 0701. Ottawa, Canada: University of Ottawa, Faculty of Social Sciences. https://socialsciences.uottawa.ca/economics/sites/socialsciences.uottawa.ca.economics/files/0701E.pdf.

Garin-Muñoz T. (2006). Inbound international tourism to Canary Islands: A dynamic panel data model. Tourism Management, 27(2), 281-291. DOI: 10.1016/j.tourman.2004.10.002.

Garin-Muñoz T., and Montero-Martín L. F. (2007). Tourism in the Balearic Islands: A Dynamic Model for International Demand using Panel Data. Tourism Management, 28(5), 1224-1235. DOI: $10.1016 /$ j.tourman.2006.09.024.

Hamal, K. (1998). Australian Outbound Holiday Travel Demand: Long-haul versus Short-haul. Australian Tourism and Hospitality Research Conference, Gold Coast, Queensland, Australia, 11-14 February 1998. Canberra, Australia: Bureau of Tourism Research.

Harris, R., \& Sollis, R. (2003). Applied Time Series Modelling and Forecasting. Chichester, England: Wiley.

Kayhan, S., Bayat, T., \& Koçyiğit A. (2013). Enflasyon Hedeflemesi Rejiminde Öğrenme Süreci ve Asimetri: Markov Switching Yaklaşımı (Learning Process and Asymmetry in Inflation Targeting Regime: Markov Switching Approach). İBF Dergisi, 8(1),191 212.

Kim, H., Park, J. H., Lee, S. K., \& Jang, S. C. S. (2012). Do expectations of future wealth increase outbound tourism? Evidence from Korea. Tourism Management, 33(5), 1141-1147. DOI: 10.1016/j.tourman.2011.11.017.

Lee, C. C., \& Chang, C. P. (2008). Tourism Development and Economic Growth: A Closer Look at Panels. Tourism Management, 29(1), 180-192. DOI: 10.1016/j.tourman.2007.02.013.

Lim, C. (2004). The Major Determinants of Korean Outbound Travel to Australia. Mathematics and Computers in Simulation, 64(3-4), 477-85. DOI: 10.1016/S0378-4754(03)00113-7.

Maloney, W. F., \& Rojas, G. V. M. (2013). How elastic are sea, sand and sun? Dynamic panel estimates of the demand for tourism. Applied Economics Letters, 12(5), 277-280. DOI: $10.1080 / 1350485042000338626$.

Mohd, T. I., \& Zahid, I. (2006). Modelling Exchange Rates Using Regime Switcing Models. Sains Malaysiana, 35(2), 55-62.

Naudé, E., \& Saayman, A. (2005). Determinants of tourist arrivals in Africa: a panel data regression analysis. Tourism Economics, 11(3), 365-391. DOI: 10.5367/000000005774352962.

Özcan, C. C. (2013) Turizm Talebini Etkileyen Ekonomik Faktörlerin Ekonometrik Analizi (Econometric Analysis of Economic Factors Affecting Tourism Demand) (Doctoral dissertation). Konya, Turkey: Necmettin Erbakan University. 
Seetaram, N. (2010). Use of Dynamic Panel Cointegration Approach to Model International Arrivals to Australia. Journal of Travel Research, 49(4), 414-22. DOI: 10.1177/0047287509346992.

Song, H., Romilly, P., \& Liu, X. (2000). An Empirical Study of Outbound Tourism Demand in the UK. Applied Economics, 32(5), 611-624. DOI: 10.1080/000368400322516.

Turkish Statistical Institute. (2015). Statistical Indicators. Retrieved 1 August, 2015 from http:// tuikapp.tuik.gov.tr/Gosterge/?locale=tr.

Uçak, H. (2011). Türkiye'nin Yurtdışı Turizm Talebi. İtisadi ve İdari Bilimler Dergisi (Journal of Economics and Administrative Sciences), 12(2).

United Nations World Tourism Organisation. (2014). Annual Report 2014. Madrid, Spain: Author.

Walle, Y. M. (2010). Tourist Flows and Its Determinants in Ethiopia. Ethiopian Development Research Institute EDRI Working Papers, June 01. Retrieved from www.edri.org.et/Resources/Working_Papers/EDRI_WP001_Tourist_Flows.pdf.

Webb, A. J., \& Chotithamwattana, C. (2013). Who Visits Thailand and Why? An Econometric Model of Tourist Arrivals by Country of Origin. Proceedings of 8th Asian Business Research Conference 1-2 April, 2013, Bangkok, Thailand.

The World Bank. (2015). World Development Indicators. Retrieved 1 January, 2015 from http://data. worldbank.org/data-catalog/world-development-indicators.

Ziramba, E., \& Moyo, B. (2013). Aggregate Outbound Tourism Demand in South Africa: an Econometric Analysis. Journal of Economics and Behavioral Studies, 5(5), 260-267. 